\title{
BUTTERFLIES OF SIRUVANI FORESTS OF WESTERN GHATS, WITH NOTES ON THEIR SEASONALITY
}

\author{
P.R.Arun \\ Salim Ali Centre for Ornithology and Natural History, Moongilpallam, Anaikatty, Coimbatore, Tamil Nadu 641108, India \\ E-mail:prarun@indimail.com
}

\begin{abstract}
The seasonal pattern in the abundance of butterflies belonging to the families, Papilionidae, Pieridae and Nymphalidae was monitored during the period of September 1994 to August 1996 in the moist deciduous forest of Siruvani, using the transect counting method. Seventy-five species of butterflies belonging to 49 genera were recorded from the area during the study. Of these 53 were encountered along the transect. The present paper also provides an account of their seasonality pattern.
\end{abstract}

\section{Keywords}

Butterflies, Lepidoptera, seasonal pattern, Siruvani, Nilgiri Biosphere Reserve, Western Ghats, southern India

\section{Introduction}

The number of Indian butterflies amount to one fifth of the world total of butterfly species. The Himalayan mountain range harbours the major share of the Indian butterfly diversity (Haribal, 1992). Although, only a quarter of India's butterfly diversity is represented in the Western Ghats, it has the characteristic of high alpha diversity of butterflies in certain locations (Gaonkar, 1996; Arun, 2000). No comprehensive systematic account of the insect fauna of this mountain range exists today (Nair \& Mathew, 1993; Mathew, 1996). However, butterflies are exceptional, are relatively well-studied and documented group of insects from this mountain range (Wynter-Blyth, 1944; Larsen, 1987, 1988; Mathew, 1990; Gaonkar, 1996). Checklists of butterflies are also available from different areas (Asaithambi, 1994; Rathinasabapathy, 1998). However the temporal dimension of the butterfly assemblages is little known from this region but for a recent report from the northern Western Ghats by Kunte (1996). Along with a checklist of butterflies from the Siruvani forests, the present paper provides information on the seasonal pattern in their occurrence as well.

\section{Study area}

The moist deciduous forests of Siruvani falling between $76^{\circ} 41^{\prime}-$ 45' E and 10 $56^{\prime}-58^{\prime} \mathrm{N}$ in the Boluvampatti Reserve Forest located in the foothills of Western Ghats about 35km west of Coimbatore, Tamil Nadu, southern India was the selected study area. The area receives good rainfall during both the north-east and southwest monsoons. The mean annual rainfall of the area during the study period was $2092 \mathrm{~mm}$, much higher than that generally received by moist deciduous zones (Champion \& Seth, 1968), owing to the closeness of the study area to one of the core zone evergreen forests of the Nilgiri Biosphere Reserve.

The transect selected for the study was about four kilometre off the forest check post at Sadivayal on the road towards the Water Filtering plant of TWAD (Tamilnadu Water Supply and Drainage) Board. The transect route of one kilometre was selected in such a way that it represented all the available habitats (Figure 1).

\section{Methodology}

The butterflies encountered along a fixed transect route of $1 \mathrm{~km}$ was recorded regularly at an interval of 10 days for a two-year period from September 1994 to August 1996. All the butterflies recorded at a distance of $5 \mathrm{~m}$ from the observer were recorded during the counts. Species of the families, Lycaenidae and Hesperiidae could not be identified accurately up to the species level in the field as they are difficult to locate and identify in the field because of their smaller sizes and cryptic colouration. Hence only total count of butterflies belonging to these families was recorded. All the counts were done on non-rainy days during morning hours between 0930 and $1030 \mathrm{hr}$. This timing was found ideal in the area based on preliminary counts done in different times of the day which revealed the maximum butterfly activity during that time.

\section{Results and Discussion}

A total of 75 species of butterflies belonging to 49 genera were observed during the present study. Abundance of butterflies fluctuated widely over the months and was most abundant in 


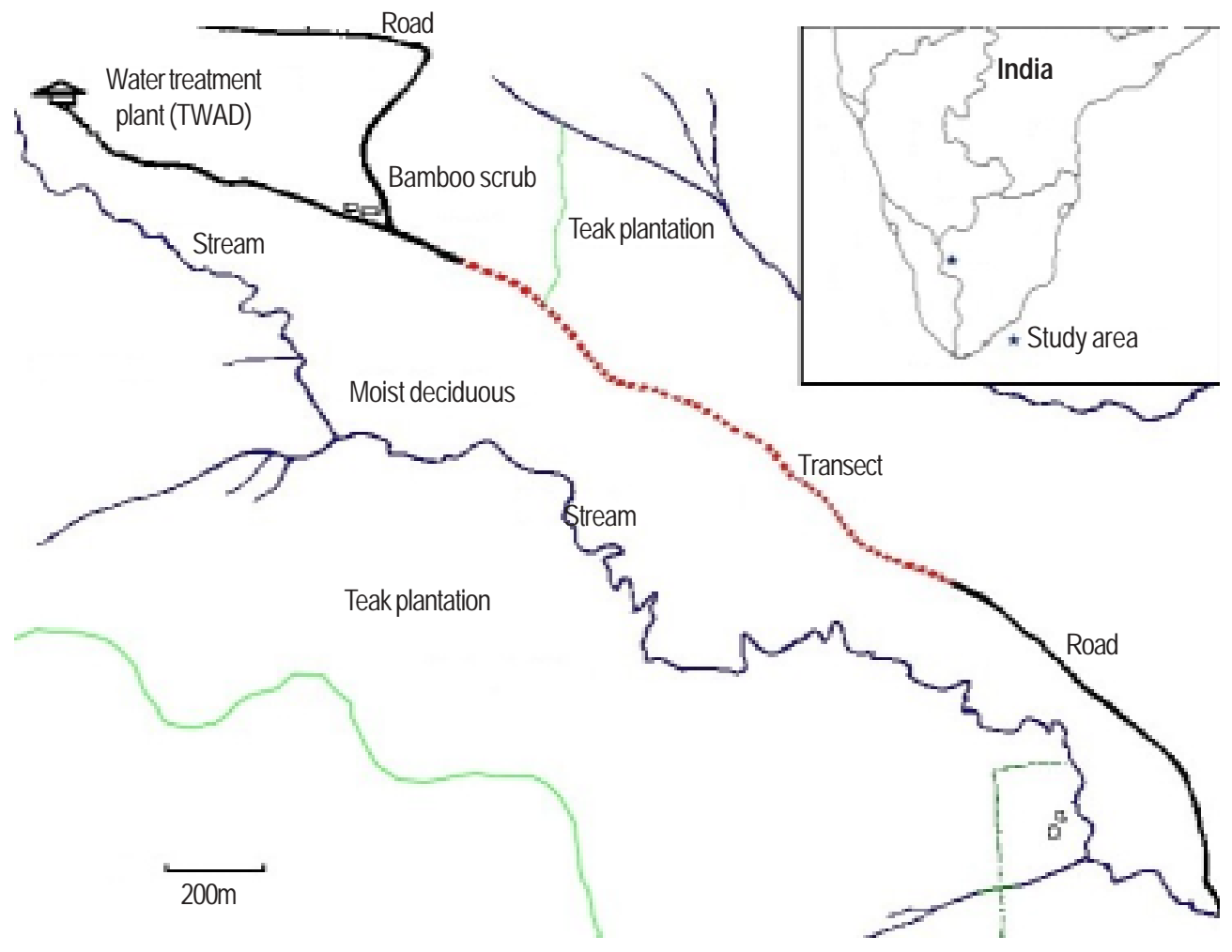

Figure 1. Map of the study area in Siruvani forests, Western Ghats, showing the location of the butterfly transect

the area during the month of August and was lowest in March (Table 2). The high peak in August was partly because of the high abundance of Whites and Yellows (Pieridae). A familywise checklist of the species observed from the study area is given in Table 1. Of the total 63 species recorded from the three families monitored (Nymphalidae, Papilionidae and Pieridae), only 53 were recorded during the transect counts.

The seasonality of 53 butterflies belonging to three major families were monitored during the study. Among the three, Nymphalidae was the most speciose family in the area. Thirty-one species belonged to this family, which accounted for around 58\% of the species richness. Papilionidae was represented by 13 species and Pieridae by 9 species (Table 2). The temporal pattern of fluctuation in the species richness of Nymphalidae showed a significant correlation with that of Papilionidae $(r=0.788, \mathrm{P}=$ 0.002; Table 3).

The temporal pattern in the occurrence of butterflies in the counts revealed a wide range of fluctuations. The temporal distribution of species during a year was only one month in the case of certain species, such as Graphium nominus, Mycalesis perseus, Junonia atlites, Junonia orithya and Tanaecia lepidea, while it was all through the year in the case of certain others, such as Pachliopta hector, Papilio polytes, Ariadne merione, Euploea core, Hypolimnas misippus, Tirumala limniace, Catopsilia pomona, Eurema hecabe and Hebomoia glaucippe (Table 1).

\section{Acknowledgements}

The study was conducted as a part of a major ecological study entitled "Breeding Strategies of Birds in a Moist Deciduous Forest of Siruvani" funded by the Ministry of Environment and forests, Govt. of India. I am highly indebted to Dr. V.S. Vijayan and Dr. P.A. Azeez of Salim Ali Centre for Ornithology and Natural History for their support and encouragement; grateful to the Staff of Tamil Nadu Forest Department, Tamil Nadu Water Supply and Drainage Board (TWAD) and Coimbatore Municipal Corporation (CMC) at Siruvani for their help and cooperation during the field work.

\section{References}

Arun, P.R. (2000). Seasonality and abundance of insects in a moist deciduous forest of Siruvani, Nilgiri Biosphere Reserve, South India. Ph.D. Thesis. Bharathiar University, Coimbatore, 236pp. (unpublished). 
Table 1. List of Butterflies observed and their seasonality.

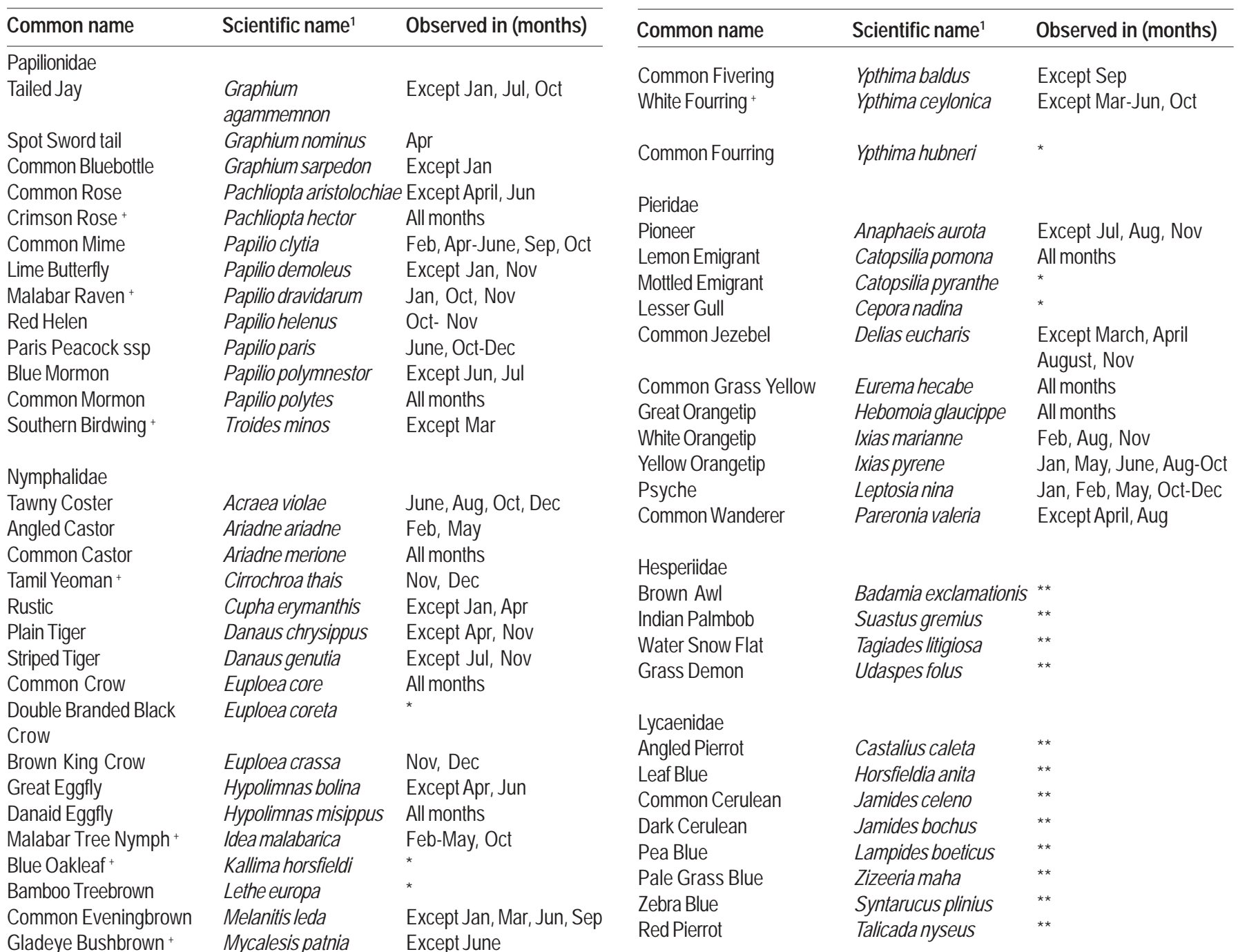

Common Bushbrown

Common Lascar

Common Sailor

Chestnut Streaked Sailor

Nigger

Glassy Tiger

Common Sergeant

Blackvein Sergeant

Common Leopard

Common Nawab

Peacock Pansy

Grey Pansy

Yellow Pansy

Chocolate Pansy

Lemon Pansy

Blue Pansy

Grey Count

Blue Tiger

Dark Blue Tiger
Graphium
agammemnon

Graphium nominus Apr

Pachliopta hecto

Papilio clytia

Papilio helenus

Papilio paris

Papilio polymnesto

Papilio polytes

roides minos

Except June

Mycalesis perseus Nov

Neptis hordonia

Neptis hylas

Neptis jumbah

Orsotrioena medus

Parantica aglea

Parathyma perius

Parathyma ranga

Phalanta phalantha

Polyura athamas

Junonia almana

Junonia atlites

Junonia hierta

Junonia iphita

Junonia lemonias

Junonia orithya

Tanaecia lepidea

Tirumala limniace

Tirumala septentrionis
*

Except Apr

Except Mar, Apr, Jun, Jul, Sep

Jan, Nov, Dec

Except Oct

Jan, Feb, Dec

Except May, Jul, Sep

Feb, Jul, Aug, Dec

Nov

Jan-Apr, Oct, Dec

All months

Except Mar, Jun, Sep

Dec

Sep

All months

* Not recorded in the transects; ** Seasonality not recorded as the species identification could not be done during the counts; ${ }^{1}$ Nomenclature following Gaonkar (1996); ${ }^{+}$Species endemic to the region of South India and Sri Lanka (Gaonkar 1996).

Table 3. Correlation (Pearson, 2-tailed) between the temporal pattern in the fluctuation of species richness in different families of butterflies.

\begin{tabular}{llll}
\hline & Nymphalidae & Papilionidae & Pieridae \\
\hline Nymphalidae & 1 & $0.788^{* \star}$ & 0.47 \\
Papilionidae & $0.788^{* \star}$ & 1 & 0.50 \\
Pieridae & 0.47 & 0.50 & 1 \\
\hline
\end{tabular}

** Correlation is significant at the 0.01 level (2-tailed) 
Table 2. Seasonal variation in species richness of different families observed during the study.

\begin{tabular}{lllll}
\hline Months & & Family & & Total \\
& Nymphalidae & Papilionidae & Pieridae & \\
\hline Sep 94 & 10 & 7 & 6 & 23 \\
Oct 94 & 8 & 7 & 3 & 18 \\
Nov 94 & 11 & 5 & 3 & 19 \\
Dec 94 & 16 & 8 & 7 & 31 \\
Jan 95 & 17 & 5 & 6 & 28 \\
Feb 95 & 15 & 6 & 6 & 27 \\
Mar 95 & 14 & 5 & 4 & 23 \\
Apr 95 & 8 & 6 & 4 & 18 \\
May 95 & 16 & 8 & 6 & 30 \\
Jun 95 & 12 & 7 & 6 & 25 \\
Jul 95 & 16 & 6 & 4 & 26 \\
Aug 95 & 15 & 7 & 5 & 27 \\
Sep 95 & 12 & 8 & 7 & 27 \\
Oct 95 & 18 & 9 & 8 & 35 \\
Nov 95 & 20 & 9 & 6 & 35 \\
Dec 95 & 23 & 8 & 7 & 38 \\
Jan 96 & 11 & 5 & 7 & 23 \\
Feb 96 & 18 & 8 & 8 & 34 \\
Mar 96 & 8 & 5 & 5 & 18 \\
Apr 96 & 12 & 7 & 4 & 23 \\
May 96 & 13 & 8 & 7 & 28 \\
Jun96 & 10 & 6 & 6 & 22 \\
Jul 96 & 8 & 4 & 5 & 17 \\
Aug 96 & 17 & 8 & 4 & 29 \\
Total Species & 31 & 13 & 9 & 53 \\
Std. Deviation & 4.09 & 1.42 & 1.47 & 5.92 \\
\hline & & & & \\
\hline & & 5 & 7 \\
\hline
\end{tabular}

Asaithambi, P. (1994). Butterflies of Mudumalai Wildlife Sanctuary, Tamil Nadu. Zoos Print 9: 1- 1.

Brown, K.S. (1997). Diversity, disturbance, and sustainable use of neotropical forests: insects as indicators for conservation monitoring. Journal of Insect Conservation 1: 1, 25-42

D'Abera, B. (1982). Butterflies of the Oriental Region. Part I. Hill house, Australia.

D'Abera, B. (1985). Butterflies of the Oriental Region. Part II. Hill house, Australia.

D’Abera, B. (1986). Butterflies of the Oriental Region. Part III. Hill house, Australia.

Gaonkar, H. (1996). Butterflies of the Western Ghats, India, including Sri Lanka: a biodiversity assessment of a threatened mountain system. Unpublished report, 51pp.

Haribal, M. (1992). The Butterflies of Sikkim and their Natural History. Sikkim Nature Conservation Foundation, Gangtok, 217pp.

Kunte, K.J. (1997). Seasonal patterns in butterfly abundance and species diversity in four tropical habitats in northern Western Ghats. Journal of Biosciences 22: 593-603.

Larsen, T.B. (1987a). Swallowtail communities in southern India. Papilio International 4: 275-294.

Larsen, T.B. (1987b). The butterflies of Nilgiri mountains of southern India (Lepidoptera: Rhopalocera). Journal of the Bombay Natural History Society 84: 26-54.

Larsen, T.B. (1987c). The butterflies of Nilgiri mountains of southern India (Lepidoptera: Rhopalocera). Journal of the Bombay Natural History Society 84: 291-316.

Larsen, T.B (1987d) The Butterflies of Nilgiri mountains of Southern India (Lepidoptera: Rhopalocera). Journal of the Bombay Natural History Society 84: 560-584. .

Larsen, T.B. (1988). The butterflies of Nilgiri mountains of southern India (Lepidoptera: Rhopalocera). Journal of the Bombay Natural History Society 85: 26-43.

Lust, N. and L. Nachtergale (1996). Towards the challenge of biodiversity in forests and forestry. Silva Gandavensis 61: 15-32.

Mathew, G. (1990). Studies on the lepidoptera fauna. In: Ecological studies and long term monitoring of the biological processes in the Silent Valley National Park. Report submitted to Ministry of Environment, Govt. of India, Kerala Forest Research Institute, 239pp. Mathew, G. (1996). Insect diversity in the Nilgiri Biosphere Reservean overview. Zoos Print 11: 11-13.

Nair, K.S.S. and G. Mathew (1993). Diversity of insects in Indian forests- the state of our knowledge. Hexapoda 5: 71-78.

Rathinasabapathy, B., B.A. Daniel and G. Mathew (1998). Butterflies of Coimbatore Zoological Park site, Anaikatty. Zoos Print 13(5):

Subadradevi and P. Davidar (2001). Response of wet forest butterflies to selective logging in Kalakkad Mundanthurai Tiger Reserve. Implications for conservation. Current Science 400-405.

Vijayan, L., V.S. Vijayan, P.R. Arun and C. Venkataraman (2001). Breeding strategies of birds in a moist deciduous forest in Siruvani. Final report. Submitted to the Ministry of Environment and Forests, India, 80pp.

Wynter-Blyth, M.A. (1944). Butterflies of the Nilgiris. Journal of the Bombay Natural History Society 44: 601-602. 